\title{
Pengawasan Ombudsman Republik Indonesia Perwakilan Jawa Tengah terhadap Maladministrasi Pungutan Liar Program Nasional Agraria di Kabupaten Kudus tahun 2017
}

\author{
Achmad Nur Fuad \\ Universitas Diponegoro Semarang, Indonesia \\ Anurfu13@gmail.com \\ Dewi Erowati \\ Universitas Diponegoro Semarang, Indonesia \\ dewierowati@yahoo.com
}

\begin{abstract}
A land certificate is an important document that shows proof of someone's ownership and rights to land.The complete systematic land registration program offers to people to make land certificates at a low cost. However, in its implementation there were many problems and irregularities encountered, especially the high collection of costs to the community.In 2017, Kudus Regency became one of the cities with the largest Prona certificate quota and there were often many problems in the implementation of Prona.Ombudsman Republik. Indonesia is present as an institution that functions to oversee and resolve public service problems that occur in the community. Ombudsman Republike Indonesia Perwakilan Jawa Tengah as the representative of the central Ombudsman supervised and tries to resolve the problems that occurred during the implementation of Prona in Kudus Regency.

This study uses qualitative research methods with a case study approach. The purpose of using this method is to dig up data and information accurately and specifically, so that the data and information produced is
\end{abstract}


complete and in-depth. Data collection techniques used were interviews with eight informants, literature review and review of documents relating to the supervision of the Ombudsman Republik Indonesia. The results of this study indicate that the supervision carried out by Ombudsman Republik Indonesia Perwakilan Jawa Tengah in supervising Prona in Kudus Regency was in accordance with its functions, duties, and authority. Supervision carried out by the Ombudsman Republik Indonesia Perwakilan Jawa Tengah is to conduct an investigation of its own initiative, conduct preventive supervision and cooperate with other law enforcement agencies. Ombudsman Republik. Indonesia Perwakilan Jawa Tengah tries to resolve the Prona problem reported by the public and Ombudsman Republik Indonesia Perwakilan Jawa Tengah also sent suggestions for improvements to stakeholders to prevent problems from recurring. The thing that was lacking in the supervision wasOmbudsman Republik. Indonesia Perwakilan Jawa Tengah did not involve the community in supervising Prona in Kudus Regency.

Keywords: Supervision, Prona, Ombudsman Republik Indonesia Perwakilan Jawa Tengah

\begin{abstract}
Abstrak
Sertifikat tanah merupakan dokumen penting yang menunjukkan tanda bukti kepemilikan dan hak seseorang atas tanah. Program pendaftaran tanah sistematis lengkap melalui Prona menawarkan kepada masyarakat untuk membuat sertifikat tanah dengan biaya yang murah. Akan tetapi, dalam pelaksanaannya banyak ditemui permasalahan dan penyimpangan, terutama pemungutan biaya ke masyarakat yang tinggi.Pada tahun 2017, Kabupaten Kudus menjadi salah satu kota yang memiliki kuota sertifikat Prona terbesar dan sering terjadi banyak permasalahan dalam penyelenggaraan Prona. Ombudsman Republik Indonesia hadir sebagai lembaga yang berfungsi untuk mengawasi dan menyelesaikan permasalahan pelayanan publik yang terjadi di masyarakat. Ombudsman Republike Indonesia Perwakilan Jawa Tengah sebagai perwakilan Ombudsman pusatmelakukan pengawasan dan berupaya untuk menyelesaikan permasalahan yang terjadi dalam penyelenggaraan Prona di Kabupaten Kudus.

Penelitian ini menggunakan metode penelitian kualitatif dengan
\end{abstract}


pendekatan studi kasus.Tujuan dari penggunaan metode tersebut adalah untuk menggali data dan informasi dengan akurat dan spesifik, supaya data dan informasi yang dihasilkan lengkap dan mendalam. Teknik pengumpulan data yang digunakan adalah wawancara dengan delapan informan, kajian pustaka dan telaah dokumen yang berkaitan dengan pengawasan Ombudsman Republik Indonesia.

Hasil dari penelitian ini menunjukean bahwa pengawasan yang dilakukan Ombudsman Republik Indonesia Perwakilan Jawa Tengah dalam mengawasi Prona di Kabupaten Kudus sudah sesuai dengan fungsi, tugas, dan wewenangnya. Pengawasan yang dilakukan olehOmbudsman Republik. Indonesia Perwakilan Jawa Tengah adalah melakukan investigasi inisiatif sendiri, melakukan pengawasan preventif dan melakukan kerjasama dengan aparat bukum lainnya. Ombudsman Republik Indonesia Perwakilan Jawa Tengah berupaya untuk menyelesaikan permasalahan Prona yang dilaporkan masyarakat danOmbudsman Republik. Indonesia Perwakilan Jawa Tengah juga mengirimkan saran perbaikan kepada instansi yang terlibat untuk mencegah permasalahan terulang kembali. Hal yang kurang dalam pengawasan tersebut adalah Ombudsman Republik. Indonesia Perwakilan Jawa Tengah kurang melibatkan masyarakat dalam melakukan pengawasan Prona di Kabupaten Kudus.

Kata Kunci: Pengawasan, Prona, Ombudsman Republik Indonesia Perwakilan Jawa Tengah

\section{A. Pendahuluan}

Sertifikat tanah merupakan dokumen pentingyang menunjukkan tanda bukti kepemilikan dan hak seseorang atas tanah. Badan Pertanahan Nasional (BPN) mencatat bahwa di wilayah Indonesia sebagian besar tanah yang dimiliki masyarakat belum bersertifikat.Kebijakan program persertifikatan tanah massal dengan program Pendaftaran Tanah Sistematis Lengkap (PTSL) melalui Program Nasional Agraria (Prona), pemerintah berusaha meningkatkan jaminan status hukum tanah milik masyarakat. Program tersebut memungkinkan masyarakat mendaftarkan aset 
tanah yang dimiliki dan mendapatkan sertifikat tanah dengan biaya yang minim.

Program persertifikatan tanah yang begitu masif digencarkan ke seluruh daerah memungkinkan terjadi permasalahan dan penyimpangan, salah satunya adalah mengenai pungutan biaya yang tidak wajar atau bisa disebut pungutan liar. Provinsi Jawa Tengah merupakan salah satu daerah yang memiliki permasalahan cukup banyak dalam hal urusan pertanahan dengan 41 laporan yang diadukan ke Ombudsman Republik Indonesia pada tahun 2017. Terlebih pada tahun tersebut banyak permasalahan mengenai pungutan liar dalam penyelenggaraan Prona.

Prona banyak menimbulkan pungutan liar yang dilakukan oleh kepala desa karena Anggaran Pendapatan dan Belanja Negara (APBN) tidak mencukupi dan hanya menanggung Rp 209.300,00 per bidang tanah ${ }^{1}$. (www. Ombudsman.go.id, Cegah Maladministrasi Dalam Program PTSL, 12 Februari 2018).Pada dasarnya peserta program Prona dibebaskan dari komponen biaya pengukuran bidang tanah, pemeriksaan tanah, pengesahan data fisik dan penerbitan sertifikat yang sudah ditanggung oleh Pemerintah. Namun, ada beberapa komponen yang tidak ditanggung Pemerintah seperti biaya materai, pembuatan dan pemasangan patok tanda batas, Bea Perolehan Hak Atas Tanah dan Bangunan (BPHTB) dan Pajak Penghasilan (PPh) dari Pengalihan Hak Atas Tanah dan Bangunan bagi yang terkena ketentuan perpajakan, semuanya menjadi beban kewajiban peserta Prona.

Alasan utama kenapa program Prona banyak terjadi pungli adalah belum adanya peraturan mengenai biaya pengurusan yang dibebankan ke masyarakat. Sehingga biaya pengurusan yang dipungut ke masyarakat hanya berdasarkan pada kesepakatan bersama masyarakat atau hanya kesepakatan antara perangkat desa saja. Hal ini memungkinkan membuka celah untuk melakukan

1 Ombudsman, Cegah Maladminstrasi dalam PTSL, diakses 12 Februari 2018, Https://www.ombudsman.go.id/artikel/r/artikel--cegah-maladministrasi-dalampenyelenggaraan-program-ptsl. 
penyalahgunaan wewenang oleh perangkat desa. Hal ini menjadikan program Prona menjadi ajang musiman bagi perangkat desa maupun kepala desa untuk mendapatkan uang besar dengan menarik uang dari masyarakat.

Lembaga Ombudsman hadir sebagai lembaga pengawasan terhadap penyelenggara Negara dengan cita-cita besar membawa perubahan menuju pemerintahan yang transparan, bersih dan bebas Kolusi, Korupsi dan Nepotisme ${ }^{2}$. Berdasarkan Pasal 1 Ayat 1 Undang-Undang Republik Indonesia Nomor 37 Tahun 2000, lembaga Ombudsman Republik Indonesia diberi kewenangan mengawasi penyelenggaraan pelayanan publik yang diselenggarakan oleh penyelenggara Negara dan pemerintah kepada masyarakat. Dalam melaksanakan tugas dan fungsinya terhadap permasalahan dalam penyelenggaraan, Ombudsman Republik Indonesia juga melakukan penilaian kepatuhan penyelenggara pelayanan publik terhadap UU RI Nomor 25 Tahun 2009 tentang Pelayaan Publik, peningkatan penyelesaian laporan masyarakat, peningkatan partisipasi masyarakat dalam pengawasan pelayanan publik, dan penyampaian saran perbaikan suatu kebijakan.

Ombudsman Republik Indonesia (ORI) mengawasi pelayanan publik dalam berbagai bidang dan jenis penanganannya pun berbeda-beda, salah satunya adalahbidang agraria dan tata ruang. Ombudsman Republik Indonesia Perwakilan Jawa Tengah sebagai perwakilan Ombudsman RI di wilayah Jawa Tengah menerima banyak laporan pungli dari masyarakat terkait program Prona. Terkait hal ini, Ombudsman Republik Indonesia perwakilan Provinsi Jawa Tengah melakukan pengawasan penyelenggaraan program-program persertifikatan tanah di delapan kabupaten/kota. Delapan daerah yang diawasi pelaksanaannya yaitu, Kudus, Kabupaten Semarang, Jepara, Pemalang, Grobogan, Brebes, Cilacap dan Kota Semarang ${ }^{3}$.

2 Sujata, Antonius, Ombudsman Indonesia: Masa Lalu, Sekarang, Dan Masa Mendatang, (Jakarta : Komisi Ombudsman Nasional), 2002, hlm. 20.

3 Ombudsman, Ini Antisipasi Kemunculan Pungli pada Prona, dikases 12 Maret 2018, Http://www.Ombudsman.Go.Id/Index.Php/Pwk/Jawa-Tengah/2347-IniAntisipasiKemunculan-Pungli-Pada-Prona.Html. 
Kabupaten Kudus menjadi salah satu daerah yang diawasi oleh Ombudsman Republik Indonesia Perwakilan Jawa Tengah. Hal tersebut dikarenakan pada tahun 2017, Kabupaten Kudus merupakan tiga kota di Jawa Tengah yang memiliki kuota sertifikasi tanah Prona terbesar dengan jumlah kuota 19.000 sertifikat tanah ${ }^{4}$. Kabupaten Kudus juga menjadi kota yang sering diberitakan dalam media terkait dengan pungutan liar di beberapa desa dalam penyelenggaraan Prona. Hal tersebut diperkuat dengan ada dua laporan masuk dari masyarakat ke Ombudsman Republik Indonesia Perwakilan Jawa Tengah terkait dengan terjadinya pungutan liar dalam penyelenggaraan Prona di Kabupaten Kudus.

Permasalahan yang kompleks dalam penyelenggaraan Prona di Kabupaten Kudus membuat Ombudsman Republik Indonesia Perwakilan Jawa Tengah melakukan pengawasan intensif dan berusaha menyelesaikan permasalahan-permasalahan dalam penyelenggaraan Prona di Kabupaten Kudus. Dalam mengupayakan pelayanan dan penyelenggaraan Prona yang baik dan bersih, Ombudsman Republik Indonesia perlu memanfaatkan tugas dan kewenangan yang dimiliki oleh Ombudsman agar bisa tercipta pelayanan publik yang baik dalam penyelenggaraan Prona baik di Kabupaten Kudus maupun di Jawa Tengah.

Penelitian ini menggunakan penelitian kualitatif dengan pendekatan studi kasus.Tujuan dari penelitian kualitatif iniialah untuk menjelaskan kasus yang terjadi secara lengkap dan mendalam. Teknik pengumpulan data yang digunakan adalah wawancara dengan delapan informan, kajian pustaka dan telaah dokumen yang berkaitan dengan pengawasan Ombudsman Republik Indonesia.

4 Bisnis.com, 19 Ribu Lahan Warga Kudus Diikutkan Prona 2017, diakses 2 Mei 2019, Https://semarang.bisnis.com/read/20170720/535/767998/19-ribu-lahan-wargakudus-diikutkan-prona-2017 


\section{B. Pembahasan}

\section{Permasalahan Penyelenggaraan Prona Terkait Maladministrasi Pungutan Liar di Kabupaten Kudus}

Penyelenggaraan Prona di Jawa Tengah memiliki potensipotensi maladministrasi yang serupa. Penyelenggaraan Prona di Kabupaten Kudus memiliki permasalahan yang lebih kompleks daripada kota-kota lainnya. Adapun fakta-fakta maladministrasi dalam penyelenggaraan Prona di Kabupaten Kudus berdasarkan temuan Ombudsman Republik Indonesia Perwakilan Provinsi Jawa Tengah adalah sebagai berikut:

a. Penyelenggaraan sosialisasi dilakukan di masing-masing desa terdapat informasi dari masyarakat bahwa oknum Pejabat Pembuat Akta Tanah ikut dalam sosialisasi tersebut;

b. Pada proses pengumpulan data/alat bukti/alas hak, masyarakat dibebani biaya materai, biaya operasional perangkat desa, patok batas dan biaya jasa PPAT sebesar Rp. 500.000,00 hingga Rp. 700.000,00;

c. Biaya tersebut dipungut oleh perangkat desa, Staf Notaris/PPAT di Kantor Pemerintah Desa dengan tanda terima dari pemerintah desa maupun Notaris/PPAT;

d. Perangkat Desa menerima penitipan pembayaran biaya pengumpulan data/alat bukti/alas hak, biaya materai, patok batas dan biaya jasa PPAT;

e. Biaya yang dikumpulkan dari masyarakat tersebut dilakukan tidak berdasarkan ketentuan peraturanperundang-undangan;

f. Biayayangdipunguttersebuttidakadapertanggungjawaban kepada masyarakat selaku pengguna layanan.

Permasalahan dalam penyelenggaraan Pendaftaran Tanah Sistematis Lengkap (PTSL) melalui Prona banyak menimbulkan 
penyelewengan maupun permasalahan di tingkat desa/kelurahan yang disebabkan oleh beberapa alasan:

1. Pemerintah Desa melakukan pungutan biaya dengan kepada peserta Pendaftaran Tanah Sistematis Lengkap melalui Prona dalam penyelenggaraan penyuluhan, pengumpulan data yuridis dan data fisik di tingkat desa, karena biaya yang timbul dari kegiatan penyuluhan masih kurang memadai.

2. Belum adanya payung hukum dan pedoman bagi Pemerintah Desa terkait mekanisme pemungutan, pengelolaan dan pertanggungjawaban biaya yang dipungut langsung dari masyarakat.

3. Terdapat beberapa desa yang membuat peraturan desa sebagai landasan hukum untuk menetapkan nominal biaya pengurusan pendaftaran tanah sistematis lengkap melalui Prona di luar dari biaya yang dibebankan kepada APBN, namun dasar penetapan biaya/tarif kepada masingmasing pemohon oleh pemerintah desa (peraturan desa) ditetapkan secara sepihak.

Berdasarkan beberapa alasan tersebut Ombudsman RI Perwakilan Jawa Tengah melakukan kajian terhadap beberapa laporan masyarakat yang diterima terkait penyelenggaraaan Pendaftaran Tanah Sistematis Lengkap melalui Prona di Kabupaten Kudus. Ombudsman RI Perwakilan Jawa Tengah menyebutkan akan terjadi indikasi maladministrasi sebagai berikut:

1. Terjadi pungutan tidak resmi yang dilakukan oleh Pemerintah Desa dalam Pendaftaran Tanah Sistematis Lengkap melalui Program Nasional Agraria (Prona);

2. Perangkat Desa menerima penitipan pembayaran biaya pengumpulan data/alat bukti/alas hak, biaya materai, patok batas dan biaya jasa PPAT dalam rangkaian kegiatan pengumpulan data yuridis dan data fisik; 
3. Biaya pungutan tidak resmi tidak terdapat pertanggungjawaban kepada masyarakat selaku pengguna layanan.

\section{Pengawasan Ombudsman Republik Indonesia Perwakilan} Jawa Tengah Terhadap Maladministrasi PTSL Prona di Kabupaten Kudus

a) Ombudsman Republik Indonesia Perwakilan Jawa Tengah Melakukan Investigasi Atas Prakarsa Sendiri

Berdasarkan Pasal 7 Undang-Undang Nomor 37 Tahun 2008, Ombudsman Republik Indonesia memiliki salah satu wewenang yaitu melakukan investigasi prakarsa sendiri terhadap dugaan maladministrasi dalam penyelenggaraan pelayanan publik. Investigasi atas inisiatif sendiri merupakan investigasi yang dilakukan dalam mengungkap kasus-kasus penyimpangan atau maladministrasi yang telah banyak terjadi di masyarakat dan merugikan masyarakat dan kasus-kasus tertentu yang menjadi sorotan publik dan telah termuat di banyak media atau kasus yang menimbulkan kerugian besar terhadap Negara ${ }^{5}$.

Tim Ombudsman Republik Indonesia Perwakilan Provinsi Jawa Tengah dalam melakukan investigasi atas inisiatif sendiri di Kabupaten Kudus menggunakan metode sebagai berikut:

1) Pelacakan Media

Tim Pengkaji melakukan penelusuran pemberitaan di media massa terkait adanya dugaan permintaan sejumlah uang penyelenggaraan PTSL yang diselenggarakan oleh Pemerintah Desa. Selanjutnya, dari hasil penelusuran tersebut maka dilakukan pengumpulan data lapangan.

5 Sujata, Antonius, Ombudsman Indonesia: Masa Lalu, Sekarang, Dan Masa Mendatang, (Jakarta : Komisi Ombudsman Nasional), 2002, hlm. 39. 
2) Under Cover/Penyamaran

Tim Pengkaji menerapkan metode penyamaran dengan secara tertutup sebagai peserta Pendaftaran Tanah Sistematis Lengkap melalui Prona khususnya pada tahapan sosialisasi.

3) Wawancara

Tim Pengkaji dalam melakukan kajian cepat dengan menggunakan metode wawancara terbuka. Tim Pengkaji melakukan wawancara terhadap pihak Kepala Desa, Kepala Kantor Pertanahan, Camat pada Pemerintah Kecamatan dan pihak yang terlibat langsung dalam penyelenggaraan PTSL melalui Prona.

Ombudsman RI Perwakilan Jawa Tengah juga bekerjasama dengan konco Ombudsman yang merupakan rekan Ombudsman dalam membantu mencari data dan informasi. Pihak yang membantu adalah rekan-rekan media, salah satunya Tribun Jateng. Tribun Jateng mempunyai kolom khusus mengenai pelayanan publik. Masyarakat banyak yang melapor ke Tribun Jateng dan laporan tersebut nantinya juga di serahkan ke Ombudsman RI Perwakilan Jawa Tengah.

Hal yang kurang dalam metode investigasi Ombudsman kali ini adalah kurang melibatkan masyarakat dalam menggali data maupun informasi. Jadi investigasi yang dilakukan oleh Ombudsman RI Perwakilan Jawa Tengah hanya dilakukan untuk mencari informasi mengenai penyelenggaraan Prona dari sisi penyedia layanan publik yakni Kepala Desa dan Kantor Pertanahan dan Ombudsman tidak menggali data dari masyarakat yang merupakan pengguna layanan publik. Meskipun begitu, investigasi atas inisiatif sendiri tersebut merupakan pengawasan utama yang dilakukan oleh Ombudsman RI Perwakilan Jawa Tengah. Sebab dengan investigasi ini Ombudsman RI Perwakilan Jawa Tengah mampu menggali lebih dalam mengenai 
penyelenggaraan PTSL Prona di Kabupaten Kudus.

Hasil laporan dari kajian investigasi inisiatif sendiri ini nantinya yang akan menjadi pegangan bagi Ombudsman RI Jawa Tengah dalam melakukan pengawasan terhadap program PTSL Prona. Hasil laporan tersebut juga akan disampaikan kepada pihak terkait dan Ombudsman akan mencari kebenarannya dengan berkonsultasi dan meminta informasi kepada Badan Pertanahan Nasional (BPN) selaku penyelenggara PTSL Prona, kepada Kejaksaan dan Kepolisian sebagai sesama aparat penegak hukum. Hasil kajian investigasi atas inisiatif sendiri juga berisikan saran korektif kepada BPN yang tujuannya untuk perbaikan program agar tidak terjadi permasalahan dan maladministrasi yang dilakukan selama penyelenggaraan PTSL Prona.

Investigasi inisiatif sendiri Ombudsman RI Perwakilan Jawa Tengah yang dilakukan di Kabupten Kudus bertempat di Desa Puyoh Kecamatan Dawe. Hasil utama yang didapatkan dari investigasi tersebut adalah Pemerintah Desa Puyoh membebankan segala biaya yang timbul tersebut kepada setiap peserta sebesar Rp 700.000,00 (tujuh ratus ribu rupiah). Biaya yang telah terkumpul sepenuhnya dikelola oleh Notaris, sedangkan Pemerintah Desa Puyoh tidak melakukan pengelolaan terhadap biaya dari peserta tersebut.

b) Pengawasan Preventif Yang Dilakukan oleh Ombudsman RI Perwakilan Jawa Tengah.

Menurut Kansil (2002:13), pengawasan pengawasan preventif merupakan pengawasan yang mengharuskan setiap peraturan daerah dan keputusan kepala daerah harus mendapatkan pengawasan.Ombudsman RI Perwakilan Jawa Tengah tidak hanya melakukan investigasi lapangan terkait pelaksanaan Prona, tetapi juga melakukan telaah setiap peraturan yang berkaitan dengan pelaksaanaan PTSL Prona, sehingga bisa disebut Ombudsman RI Perwakilan Jawa 
Tengah melakukan pengawasan preventif. Adapun peraturan perundang-undangan yang menjadi bahan pemeriksaan Tim Pengkaji Ombudsman RI Perwakilan Jawa Tengah adalah sebagai berikut:

1) Surat Edaran Gubernur Provinsi Jawa Tengah Nomor: 590/000/26/69 tentang Tindak Lanjut Pelaksanaan Prona di Jawa Tengah.

2) Keputusan Kepala Desa Puyoh Nomor 50 Tahun 2016 Tentang Rincian Biaya Operasional Program Sertifikat Tanah Proyek Nasional (Prona) Tingkat Desa Puyoh Tahun 2017.

Hasil kajian dan analisis data yang dilakukan Ombudsman RI Perwakilan Jawa Tengah, serta hasil dari permintaan keterangan dari BPN Kabupaten Kudus, Ombudsman melakukan penilaian terhadap pelaksanaan Prona di Kabupaten Kudus. Ombudsman RI Perwakilan Jawa Tengah melakukan penilaian dalam empat hal, yakni sebagai berikut:

1. Ombudsman RI Perwakilan Jawa Tengah menilai ketaatan penyelenggara PTSL Prona di Kabupaten Kudus terhadap peraturan perundang-undangan yang berlaku.

2. Ombudsman RI Perwakilan Jawa Tengah menilai apakah penyelenggaraan PTSL Prona di Kabupaten Kudus sesuai dengan pedoman anggaran yang berlaku.

3. Ombudsman RI Perwakilan Jawa Tengah menilai apakah penyelenggaraan PTSL Prona di Kabupaten Kudus dilaksanakan secara ekonomis, efisien, dan efektif.

4. Ombudsman RI Perwakilan Jawa Tengah dapat mendeteksi adanya kecurangan atau penyimpangan dalam penyelenggaraan PTSL Prona di Kabupaten 
Kudus.

Ombudsman RI Perwakilan Jawa Tengah menilai bahwa penyelenggaraan Prona di Kabupaten Kudus telah mengacu dan sesuai dengan peraturan perundang-undangan yang terkait dengan penyelenggaraan Prona, tetapi belum sesuai dengan pedoman anggaran yang telah ditetapkan karena dalam pelaksanaannya pemerintah desa dalam memungut biaya tidak sesuai rancangan anggaran biaya yang telah dibuat. Ombudsman RI Perwakilan Jawa Tengah juga menemukan kecurangan terkait dengan biaya yang tidak wajar dan pelibatan oknum PPAT dalam penyelenggaraan Prona.

c) Pengawasan Kolaboratif Melalui Kerjasama Antar Lembaga

Berdasarkan Pasal 7 Undang-Undang Nomor 37 Tahun 2008, Ombudsman Republik Indonesia memiliki tugas untuk melakukan koordinasi dan kerjasama dengan lembaga negara atau lembaga lainnya. Ombudsman Juga mempunyai tugas untuk membangun jaringan kerja yang nantinya akan memudahkan Ombudsman Republik Indonesia dalam menggali data dan informasi. Dalam Pengawasan program Prona di Kabupaten Kudus, Ombudsman Republik Indonesia Perwakilan Provinsi Jawa Tengah telah berupaya melakukan koordinasi dan kerjasama dengan beberapa instansi pelayanan publik untuk menggali data dan informasi mengenai pelaksaanaan Prona di Kabupaten Kudus, sekaligus mengungkap dugaan maladministrasi yang terjadi selama ini. Koordinasi yang dilakukan adalah konsolidasi dengan seluruh pemangku pelayanan publik dan pihak yang terkait dalam pelaksanaan program Prona di Kabupaten Kudus.

Ombudsman melakukan kerjasama dengan berbagai instansi dengan melakukan pertukaran data yang antara 
lain ditujukan untuk meningkatkan keakuratan data dalam pengawasan dan penyelesaian maladministrasi terhadap pungli Prona. Kerjasama dengan Kantor Pertanahan Kudus, Kejaksaan Negeri Kudus, Kepolisian Resort Kabupaten Kudus, dan Inspektorat Kabupaten Kudus, diharapkan pengawasan dan penyelesaian maladministrasi oleh Ombudsman dapat memberikan manfaat yang optimal bagi terlaksananya program Prona dengan baik, sehingga tujuan dan sasaran yang terdapat dalam program Prona dapat tercapai.

Ombudsman Republik Indonesia Perwakilan Jawa Tengah bekerjasama dan berkoordinasi dengan Badan Pertanahan Nasional (BPN) sebagai penyelenggara pelayanan P'TSL Prona. Kerjasama dan koordinasi tersebut tentu diperlukan untuk hal permintaan keterangan, salinan dokumen mengenai penyelenggaraan PTSL Prona yang diperlukan Ombudsman untuk memperoleh kesimpulan kajian. Ombudsman Republik Indonesia Perwakilan Jawa Tengah bekerjasama dengan Kejaksaan Negeri untuk melihat apakah tindakan panitia PTSLProna yang memungut biaya merupakan tindak pidana/bukan. Ombudsman Republik Indonesia Perwakilan Jawa Tengah juga bekerjasama dengan kepolisian untuk melihat perspektif Aparat Penegak Hukum dalam melihat fenomena permintaan uang dalam penyelenggaraan PTSL/Prona.

Dalam pengawasan penyelenggaraan pelayanan publik persiapan PTSL Prona di Kabupaten Kudus, Ombudsman RI Perwakilan Jawa Tengah mewujudkan forum konsolidasi seluruh pihak yang terlibat terutama pemangku pelayanan publik sebagai komunikasi antar lembaga, sharing informasi mengenai penyelenggaraan pelayanan PTSL Prona. Forum ini mempertemukan seluruh pemangku pelayanan publik dan stakeholders untuk bersinergi, melakukan kerja sama dan 
berkoordinasi untuk memperbaiki, mencegah dan menindak segala hal yang berkaitan dengan dugaan maladministrasi dalam program Prona. Pihak yang diundang adalah Badan Pertanahan Nasional Kudus, Kepolisian Resort Kudus, dan Kejaksaan Negeri Kudus. Ombudsman mengadakan Forum Group Discussion bertujuan untuk meningkatkan pengawasan dengan kolaborasi antar lembaga.

\section{Cara Penyelesaian Maladministrasi Program Prona oleh Republik Indonesia Perwakilan Jawa Tengah di Kabupaten Kudus}

\section{a. Penyelesaian Maladministrasi Program Prona dari Laporan Masyarakat}

Ombudsman Republik Indonesia menerima setiap laporan dan aduan dari masyarakat mengenai maladministrasi perihal penyelenggaraan pelayanan publik. Dalam pengawasan program PTSL Prona Ombudsman Republik Indonesia menerima laporan aduan masyarakat yang disampaikan secara langsung, surat, e-mail, telepon dan media lainnya yang ditujukan langsung kepada Ombudsman Republik Indonesia.

Ombudsman Republik Indonesia Perwakilan Jawa Tengah menerima beberapa laporan mengenai dugaan maladministrasi dalam pelaksanaan program PTSL Prona terutama terkait pungutan liar. Ombudsman sebagai lembaga pengawas penyelenggaraan pelayanan publik berkewajiban untuk menindaklanjuti laporan tersebut dengan peraturan yang berlaku.

Ombudsman RI Perwakilan Jawa Tengah memberikan pelayanan kepada masyarakat secara prima guna bisa memenuhi kebutuhan masyarakat dan bisa memecahkan permasalahan yang dihadapi oleh masyarakat. Pelayanan 
yang diberikan oleh Ombudsman RI Perwakilan Jawa Tengah diberikan semaksimal mungkin kepada masyarakat dengan memperhatikan prinsip-prinsip pelayanan publik yang baik. Ombudsman RI Perwakilan Jawa Tengah menerima dan menindaklanjuti laporan masyarakat selalu mengacu pada peraturan yang ada, yakni Undang-Undang Nomor 37 Tahun 2008, Undang-Undang Nomor 25 Tahun 2009 dan Peraturan Ombudsman Nomor 26 Tahun 2017.

Ombudsman Republik Indonesia menerima beberapa pengaduan mengenai dugaan maladministrasi dalam penyelenggaraan program PTSL Prona di Kabupaten Kudus. Dari beberapa laporan tersebut, Ombudsman Republik Indonesia mendapatkan satu laporan yang diduga terdapat unsur maladministrasi. Ombudsman Republik Indonesia Perwakilan Jawa Tengah melakukan pemeriksaan dan penyelesaian laporan sesuai Peraturan Ombudsman Nomor 26 Tahun 2017. Dalam hal ini yang diduga melakukan tindak maladministrasi adalah perangkat desa. Ombudsman kemudian meminta klarifikasi secara tertulis, klarifikasi langsung dan melakukan pemeriksaan lapangan. Hasil dari pemeriksaan tersebut tidak terbukti adanya maladministrasi tetapi ditemukan bukti-bukti adanya potensi maladministrasi. Meskipun tidak ditemukan adanya maladministrasi, Ombudsman Republik Indonesia Perwakilan Jawa Tengah tetap memberikan himbauan dan saran korektif kepada instansi yang terlibat dalam permasalahan tersebut.

Hal yang kurang adalah Ombudsman RI Perwakilan Jawa Tengah hanya menyelesaikan Prona berdasarkan laporan yang diajukan masyarakat ke Ombudsman. Jadi, masyarakat harus melapor dulu ke Ombudsman, sehingga Ombudsman bisa menindaklanjutinya. Jika masyarakat tidak melapor ke Ombudsman, maka Ombudsman tidak bisa menyelesaikan permasalahan karena keterbatasan sumber 
daya.

\section{b. Upaya Ombudsman RI Jawa Tengah Dalam Perbaikan Dan Pencegahan Maladministrasi Dalam Program Prona}

Pengawasan yang dilakukan Ombudsman Republik Indonesia baik di pusat maupun daerah bersifat korektif dan preventif dalam pelaksanaannya. Pengawasan oleh Ombudsman Republik Indonesia adalah mengoreksi dan mencegah kesalahan terjadi lagi di masa depan, artinya Ombudsman akan melakukan perbaikan untuk merubah atau mengganti peraturan, program ataupun kebijakan yang memungkinkan terjadi maladministrasi supaya tidak terjadi maladministrasi lagi.

Dengan adanya potensi-potensi maladminstrasi dalam penyelenggaraan Prona di Kabupaten Kudus, Ombudsman RI Perwakilan Jawa Tengah dalam menyelesaikan laporan masyarakat memberikan saran perbaikan dan beberapa pertimbangan. Ombudsman Republik Indonesia Perwakilan Jawa Tengah meminta kepada Badan Pertanahan Nasional Kabupaten Kudus untuk selalu memberikan pendampingan kepada Pemerintah Desa dalam penyelenggaraan PTSL Prona.Ombudsman RI Perwakilan Jawa Tengah juga meminta kepada Kepala Desa jika dalam menyelenggarakan Prona, setiap keputusan yang diambil baik terkait dengan pungutan biaya kepada masyarakat maupun keputusan yang lain agar dimasukkan dalam Surat Keputusan Kepala Desa sebagai dasar hukum yang sah.

Berdasarkan temuan-temuan Ombudsman Republik Indonesia Perwakilan Jawa Tengah dalam penyelengaraan Prona di Kabupaten Kudus, Ombudsman Republik Indonesia mengirimkan saran dan pertimbangan kepada Kementerian Agraria dan Tata Ruang tentang permasalahan 
Penyelenggaraan Prona. Saran yang diberikan adalah:

1. Menteri Agraria Dan Tata Ruang agar melakukan koordinasi dengan Kementerian Keuangan RI terkait pembebanan anggaran dalam kegiatan Pendaftaran Tanah Sistematis Lengkap.

2. Menteri Agraria Dan Tata Ruang/Badan Pertanahan Nasional RI dan Kementerian Dalam Negeri RI agar menyusun suatu kebijakan secara nasional yang diperuntukkan bagi Pemerintah Daerah sebagai landasan hukum terkait biaya dalam hal sumber pendanaan Pendaftaran Tanah Sistematis Lengkap bersumber dari luar APBN.

3. Menteri Agraria Dan Tata Ruang/Badan Pertanahan Nasional RI melakukan koordinasi dengan TP4P Kejaksaan Agung RI terkait perumusan kebijakan mengenai pungutan biaya yang dilakukan oleh Pemerintah Desa kepada masyarakat selaku pengguna layanan.

4. Menteri Agraria Dan Tata Ruang/Badan Pertanahan Nasional RI agar melakukan pendampingan kepada Pemerintah Desa dalam penyelenggaraan Pendaftaran Tanah Sistematis Lengkap.

Setelah Ombudsman RI Perwakilan Jawa Tengah memberikan saran dan pertimbangan berupa saran korektif yang ditujukan kepada Menteri Agraria Dan Tata Ruang, hasil yang didapat adalah

1. Menteri Agraria Dan Tata Ruang/Badan Pertanahan Nasional RI bersama Menteri Dalam Negeri dan Menteri Desa Pembangunan Daerah Tertinggal dan Transmigrasi menerbitkan Surat Keputusan Bersama (SKB) 3 Menteri Nomor: 25/SKB/V/2017, Nomor: 590-3167A Tahun 
2017, Nomor: 34 Tahun 2017 tentang pembiayaan persiapan pendaftaran tanah sistematis lengkap.

2. Menteri Agraria Dan Tata Ruang/Badan Pertanahan Nasional RI saat kini sedang mengkaji mengenai pembuatan Standar Operasional Prosedur (SOP) mengenai pelaksanaan PTSL melalui Prona sampai di tingkat desa.

Setelah diterbitkannya SKB 3 Menteri Ombudsman RI Perwakilan Jawa Tengah melakukan tindakan pencegahan terjadinya pungli PTSL Prona baik di Kabupaten Kudus maupun di Jawa Tengah dengan memberikan saran. Pertama, perlu didorong kepada Kantor Pertanahan di Kabupaten/ kota dan Pemerintah Daerah setempat guna melakukan sosialisasi atas SKB 3 (tiga) menteri terkait pembiayaan dalam program PTSL Prona. Kedua Inspektorat dan Kantor Pertanahan Kabupaten/Kota melakukan pendampingan dalam memberikan pemahaman peraturan perundangundangan terkait PTSL Prona kepada Kepala Desa dan perangkat. Ketiga, menghimbau kepala Desa/Lurah untuk melakukan berkonsultasi dengan Kejaksaan Negeri dan Bagian Hukum di Pemda setempat. Jika hal tersebut dilakukan Kepala Desa/Lurah makan dapat mencegah terjadinya maladministrasi dan mencegah perbuatan pidana dalam penyelenggaraan PTSL melalui Prona. ${ }^{6}$

\section{Simpulan}

Ombudsman RI Perwakilan Jawa Tengah dalam melaksanakan pengawasan terhadap program PTSL Prona di Kabupaten Kudus telah mengacu pada setiap wewenang yang dimiliki Ombudsman Republik Indonesia sesuai dengan peraturan yang berlaku yakni Undang-Undang Nomor 37 Tahun 2008. Ombudsman RI Perwakilan Jawa Tengah dalam melakukan pengawasan terhadap

6 www.Ombudsman.go.id, dikases 24 Agustus 2018. 
penyelenggaraan Prona di Kabupaten Kudus melakukan tiga tindakan. Pertama, Ombudsman RI Perwakilan Jawa Tengah melakukan investigasi inisiatif sendiri dengan turun lapangan secara langsung dengan menggunakan metode wawancara, observasi, telaah dan penyamaran. Kedua, Ombudsman RI Perwakilan Jawa Tengah melakukan pengawasan preventif, yakni menelaah dan mengkaji peraturan yang berkaitan dengan pelaksanaan PTSL Prona di Kabupaten Kudus. Ketiga, Ombudsman RI Perwakilan Jawa Tengah mewujudkan pengawasan kolaboratif dengan kerjasama antar lembaga, yakni Ombudsman RI Perwakilan Jawa Tengah menggandeng aparat penegak hukum dan penyelenggara pelayanan publik lain yang berkaitan dengan penyelenggaraan PTSL Prona untuk ikut mengawasi Prona. Kekurangan terbesar Ombudsman RI Perwakilan Jawa Tengah dalam melakukan pengawasan Prona di Kabupaten Kudus adalah kurang melibatkan masyarakat dalam pengawasan, baik dari permintaan informasi maupun pelibatan dalam acara diskusi.

Ombudsman RI Perwakilan Jawa Tengah dalam menyelesaikan dugaan maladministrasi program PTSL Prona di Kabupaten Kudus menggunakan dua cara. Pertama, Ombudsman menyelesaikan laporan dari masyarakat sesuai peraturan Ombudsman Nomor 26 Tahun 2017. Ombudsman Republik Indonesia Perwakilan Jawa Tengah dalam menyelesaikan maladministrasi hanya berdasarkan dari laporan masyarakat. Jika masyarakat tidak melapor maka Ombudsman RI Perwakilan Jawa Tengah tidak akan mengatahui permasalahan masyarakat. Kedua, Ombudsman RI Perwakilan Jawa Tengah melakukan perbaikan program PTSL Prona di Kabupaten Kudus dengan mengirimkan saran korektif kepada instansi yang terlibat yakni Badan Pertanahan Nasional dan Kepala Desa. Ombudsman RI Perwakilan Jawa Tengah juga mengirimkan saran ke Kementerian Agraria dan Tata Ruang dan direspon dengan diterbitkannya Surat Keputusan Bersama Tiga Menteri. Ombudsman RI Perwakilan Jawa Tengah juga melakukan tindakan 
pencegahan dengan memberikan beberapa saran pertimbangan kepada instansi terkait, sehingga kesalahan-kesalahan yang terjadi tidak akan terulang kembali di masa depan.

Berdasarkan kesimpulan diatas tersebut, penulis memberikan saran sebagai berikut:

1. Ombudsman Republik Indonesia Perwakilan Jawa Tengah perlu meningkatkan partisipasi masyarakat dengan melibatkan masyarakat dalam setiap pengawasan yang dilakukan oleh Ombudsman, baik dalam investigasi, kegiatan diskusi atau kegiatan Ombudsman yang lainnya.

2. Ombudsman Republik Indonesia Perwakilan Jawa Tengah diharapkan untuk menambah jumlah asisten yang nantinya dapat ditempatkan di setiap kabupaten/ kota.

3. Ombudsman Republik Indonesia Perwakilan Jawa Tengah perlu meningkatkan inisiatif pengawasan dengan cara bekerjasama dengan instansi maupun lembaga yang memiliki portal aduan/laporan masyarakat.

4. Ombudsman Republik Indonesia Perwakilan Jawa Tengah perlu mempublikasikan hasil pengawasan yang berupa hasil kajian dan laporan pengawasan.

\section{DAFTAR PUSTAKA}


Fadhilah, Laili, "Urgensitas Ombudsman Dalam Pengawasan Pelayanan Publik", Jurnal Pendidikan Pancasila Dan Kewarganegaraan. 28(2), (2015).

Imam Susanto, Muhammad, “Tinjauan Yuridis Terhadap Eksistensi LembagaOmbudsman Republik Indonesia Perwakilan Riau Dalam Pelaksanaan Fungsi Pengawasan Untuk Mewujudkan Pemerintahan Yang Baik Di Provinsi Riau". Jurnal Online Mahasiswa. 1(2) (2014).

Kansil, CST, Pengantar Ilmu Hukum Dan Tata Hukum Indonesia, Jakarta: Balai Pustaka, 2002.

Malian, Murtir, Menimbang Perlunya Komisi Ombudsman di Daerah dalam Ombudsman Daerah, Mendorong Pemerintahan Yang Bersib. Kerjasama PUSHAM UII dengan Partnership Kemitraan dan Governance Reform in Indonesia. 2003.

Sujata, Antonius, Peranan Ombudsman Dalam Rangka Pemberantasan Dan Pencegahan Korupsi Serta Penyelenggaraan Pemerintahan Yang Bersih, Jakarta: Komisi Ombudsman Nasional, 2005.

Sujata, Antonius, Ombudsman Indonesia: Masa Lalu, Sekarang, Dan Masa Mendatang, Jakarta : Komisi Ombudsman Nasional, 2002.

Sujata, Antonius Dan Surahman, Ombudsman Indonesia di Tengah Ombudsman Internasional, Jakarta: Komisi Ombudsman Nasional, 2002.

Triono, Agus. "Eksistensi Lembaga Pengawasan Ombudsman Dalam Penyelenggaraan Pelayanan Publik Di Daerah". Jurnal Sosiologi. 17(1)

Sumber Internet:

Https://www.ombudsman.go.id/artikel/r/artikel--cegah- 
maladministrasi-dalam-penyelenggaraan-program-ptsl Diakses Pada 12 Februari 2018.

Http:/ / www.Ombudsman.Go.Id/Index.Php/Pwk/JawaTengah/2347-Ini-AntisipasiKemunculan-Pungli-PadaProna.Html Diakses Pada 12 Maret 2018.

Https:/ / semarang.bisnis.com/read/20170720/535/767998/19ribu-lahan-warga-kudus-diikutkan-prona-2017 Diakses pada 2 Mei 2019. 
